\title{
Kamrai tachycardiák katéterablatiós kezelése
}

\author{
Mihálcz Attila dr. ${ }^{1}$ - Szili-Török Tamás dr. ${ }^{2}$ - Tóth Kálmán dr. ${ }^{3}$ \\ ${ }^{1}$ Gottsegen György Országos Kardiológiai Intézet, Budapest \\ ${ }^{2}$ Thorax Centre, Erasmus MC, Rotterdam \\ ${ }^{3}$ Pécsi Tudományegyetem, Általános Orvostudományi Kar, Klinikai Központ, I. Belgyógyászati Klinika, Pécs
}

\begin{abstract}
Az utóbbi két évtizedben a katéterablatiós technológia és az ablatiós stratégiák fejlődésével jelentős előrelépés történt a kamrai tachycardiák ablatiós kezelésében. Jelen összefoglaló közlemény célja a kamrai ritmuszavarok aktuális katéterablatiós kezelésének áttekintő ismertetése. A szerzők részletezik a katéterablatiós kezelés technikai alapjait, a kamrai tachycardiák ablatiós kezelésének javallatait és ellenjavallatait, a beavatkozás előtti és az azt követő vizsgálatokat. Ezt követően a kamrai tachycardiák csoportosításán keresztül az egyes típusok katéteres ablatiójának jellemzőit ismertetik. Ezzel párhuzamosan kitérnek az adott ritmuszavar kezelésével kapcsolatos eredményekre is. Összegzésképpen kiemelik, hogy a katéteres ablatio sikeresen alkalmazható eszközös beavatkozás a kamrai tachycardiák kezelésében. Megfelelő javallat esetén a kezelést lehetőleg minél korábban be kell iktatni a terápiás stratégiába. Orv. Hetil., 2015, $156(25), 995-1002$.
\end{abstract}

Kulcsszavak: kamrai tachycardia, ablatio, elektrofiziológia

\section{Catheter ablation of ventricular tachycardias}

Catheter ablation of ventricular tachycardias emerged significantly as standard therapy in the past 20 years. In this review recent advances in catheter ablation of ventricular tachycardias are discussed. The authors first present in details the technical aspects of ablation strategies, main indications and contraindications of ventricular tachycardia ablation and the necessary pre- and postinterventional diagnostic tests. Outcome is also discussed in different forms of ventricular tachycardias in detail. The authors summarize the safety and efficacy of catheter ablation of ventricular arrhythmias. They recommend that ablation of ventricular tachycardias should be considered earlier in patients with and without structural heart disease.

Keywords: ventricular tachycardia, ablation, electrophysiology

Mihálcz, A., Szili-Török, T., Tóth, K. [Catheter ablation of ventricular tachycardias]. Orv. Hetil., 2015, 156(25), 995-1002.

(Beérkezett: 2015. március 16.; elfogadva: 2015. április 23.)

\begin{abstract}
Rövidítések
ARVC = arrhythmogen jobb kamrai cardiomyopathia; $\mathrm{CMP}=$ cardiomyopathia; $\mathrm{CT}=$ komputertomográfia; $\mathrm{EAM}=$ elektroanatómiai térképezőrendszer; ECHO = echokardiográfia; EGM = intracardialis elektrogram; EKG = elektrokardiogram; EP = elektrofiziológia; $\mathrm{ICD}=$ implantálható cardioverter-defibrillátor; ICE $=$ intracardialis ultrahang; LVEF = bal kamrai ejekciós frakció; LVOT = bal kamrai kiáramlási pálya tachycardia; $\mathrm{MR}=$ mágneses rezonancia; $\mathrm{RF}=$ rádiófrekvenciás; $\mathrm{RMN}=$ mágneses navigációs rendszer; $\mathrm{RVOT}=$ jobb kamrai kiáramlási pálya tachycardia; $\mathrm{VF}=\mathrm{kam}-$ rafibrilláció; $\mathrm{VT}=$ kamrai tachycardia
\end{abstract}

A kamrai tachycardiák (VT) két nagy csoportját különböztetjük meg, amelyek patofiziológia, prognózis és terápia szempontjából jól elkülöníthetôk. Az idiopathiás VT-k strukturális szívizombetegséggel nem járó kamrai ritmuszavarok, és ezen csoport mintegy 10-20\%-át teszik ki [1]. A VT-k túlnyomó többsége azonban strukturális szívizombetegséggel járó ritmuszavar, amely az elóbbinél nagyobb mortalitással jellemezhetô [2]. Az elmúlt évtizedekben természetesen mindkét csoport gyógyszeres és utóbb már eszközös terápiás kezelése is az orvostudomány nagy feladatai közé tartoztak és tar- 
toznak jelenleg is. Ez különösen igaz az eszközös terápiás lehetőségek területén, amelyek hatalmas fejlődésen mentek keresztül. Mintegy 35 évvel ezelőtt a gyógyszeres terápiára rezisztens VT-k kezelésének elsődleges és egyetlen alternatívája a sebészi kezelés volt. Ennek segítségével akkoriban mintegy 80-90\%-os sikerarányt értek el, ugyanakkor a mütéti mortalitás 5-15\% között volt [3]. 1983-ban írták le először az elektromos áram sikeres intracardialis alkalmazását, jobb kamrai kiáramlási pálya tachycardia (RVOT) ablatiója során [4]. Ezt követően a katéterablatiós technika fejlődése, valamint az endocardialis térképezéssel gyưjtött tapasztalatok lehetővé tették

1. táblázat

Kamrai tachycardiák (VT) katéteres ablatiójának javallatai

Strukturális szívbetegségben (korábbi szívinfarktus, DCM, ARVC, korábbi szívizomgyulladás stb.)

A VT katéteres ablatiója javasolt:

1. Tünetekkel járó tartós (>30 s) monomorf VT esetén, sikeres ICD-terápiás beavatkozást követően is, amely VT ismételten fellép antiarrhythmiás gyógyszeres kezelés ellenére, illetve gyógyszer-intolerancia vagy egyéb ellenjavallat fennállásakor.

2. Folytonos monomorf VT vagy elektromos vihar $(\geq 3 \mathrm{VT} / 24$ óra) esetén, amelyek hátterében nincs reverzíbilis kiváltó tényező.

3. Gyakori VES, nem tartós VT vagy egyéb VT-k esetében, amelyek kamrai diszfunkció hátterében állhatnak.

4. Tawara-szár vagy fascicularis VT-k esetén.

5. Ismétlődő polimorf VT vagy VF esetén, amelyek gyógyszeres terápiával nem befolyásolhatóak, és felmerül egy ablatióval kezelhető arrhythmogen trigger szerepe.

A VT katéteres ablatiója mérlegelendő:

1. Egy vagy több tartós monomorf VT-epizód esetén, amelyek I-es vagy III-as csoportú antiarrhythmiás gyógyszeres kezelés ellenére lépnek fel.

2. Ismétlődő tartós monomorf VT-k esetén, korábbi szívinfarktust követően, amennyiben LV EF >30\%, és több mint egyéves túlélés valószínúsíthetô, az amiodaronterápia alternatívájaként.

3. Hemodinamikailag tolerálható tartós monomorf VT-k esetén, korábbi infarktus és $35 \%$ feletti LV-EF fennállásakor, még hatásos gyógyszeres terápia esetében is.

Strukturális szívbetegség nélkül

A katéteres ablatio javasolt idiopathiás VT-k esetében, ha:

1. monomorf VT tüneteket okoz;

2. monomorf VT során az antiarrhythmiás kezelés hatástalan, nem tolerálható vagy egyéb okból nem javasolható;

3. ismétlődő tartós polimorf VT vagy VF esetén, amelyek gyógyszeres terápiával nem befolyásolhatóak és felmerül egy ablatióval kezelhető arrhythmogen trigger szerepe.

ARVC $=$ arrhythmogen jobb kamrai cardiomyopathia $;$ DCM $=$ dilatatív cardiomyopathia; $\mathrm{EF}=$ ejekciós frakció; $\mathrm{ICD}=$ implantálható cardioverter-defibrillátor; LV = bal kamra; VES = kamrai extrasystole; $\mathrm{VF}=$ kamrafibrilláció $; \mathrm{VT}=$ kamrai tachycardia . a VT-k mechanizmusainak pontosabb megismerését. Leírásra került a reentry körök és a lassan vezetó régiók kamrai ritmuszavarokban játszott szerepe, valamint ablatiós célterületként meghatározott jelentősége [5]. A rádiófrekvenciás (RF) energia használatával sikerült szabályozni a roncsolandó szívizomterület nagyságát, így megnyílt a lehetőség a gyógyszeres terápiára refrakter VT-k katéterablatiós kezelésére [6].

\section{Kamrai tachycardiák ablatiós kezelésének indikációja}

A VT-k RF-ablatiós kezelésével kapcsolatban az EHRA(European Heart Rhythm Association-) és HRS- (Heart Rhythm Society-) szakértők által először 2009-ben öszszeállított konszenzus fogalmaz meg irányelveket [7], a beavatkozásokat javasolt, mérlegelendō vagy ellenjavallt csoportokra bontva (1. és 2. táblázat). A döntéshozatalban az irányelvek mellett természetesen az esetek egyedi jellemzői is fontos szerepet játszanak. Ilyenek például a tervezett beavatkozás várható előnyei/rizikófaktorai, a beteg és ritmuszavarának jellegzetességei, valamint a beavatkozáshoz adott személyi és tárgyi feltételek.

2014-ben jelent meg az újabb, a VT-k kezelését részletező konszenzus, amely az EHRA és HRS mellett már az APHRS (Asia Pacific Heart Rhythm Society) szakértőinek bevonásával készült [8]. Ez a konszenzus szerkezetében némileg eltér a 2009-es változattól. A VT-ket klinikai megjelenés alapján csoportosítja: például halmozott kamrai extrasystolék (VES), nem tartós VT-k, tartós monomorf vagy polimorf VT-k stb. Az egyes csoportokat részletesen tárgyalja klinikai előfordulás, diagnosztikai protokollok és gyógyszeres/eszközös terápiás javaslatok szempontjából [8].

A tartós VT-k gyakori előfordulása magasabb mortalitással jár [9], így már a 2009-es konszenzus is javasolja például ennek a csoportnak korai RF-ablatiós kezelését. Az eszközös terápiás lehetőségek közé tartozik az utóbbi évtizedekben hatalmas fejlődésen átment implantálható cardioverter-defibrillátor (ICD) terápia is, amelynek 1980-ban történt bevezetése óta mortalitáscsökkentő hatása egyértelmúen bizonyított [10]. Mindezek mellett a gyógyszeres terápia jelentősége sem csökkent, akár akut vagy tartós alkalmazását tekintjük. Gyógyszeres te-

\section{2. táblázat}

VT katéteres ablatio ellenjavallatai

1. Mobilis kamrai thrombus esetén (epicardialis ablatio megfontolandó).

2. Tünetmentes VES vagy nem tartós VT-k estén, amelyek nem okozhatnak kamrai diszfunkciót.

3. Tranziens VT-k esetén, amelyek hátterében reverzíbilis okok feltételezhetők: akut ischaemia, hyperkalaemia, gyógyszer indukálta „torsades de pointes”.

VES = kamrai extrasystole $; \mathrm{VT}=$ kamrai tachycardia 
rápiával a szükséges ICD-aktivitás gyakorisága csökkenthetô [11], ugyanakkor a kezelésnek gyakori velejárója a nem megfelelő terápiás hatékonyság vagy egyéb káros mellékhatás. Ennek ellenére a gyógyszeres terápiának kiemelkedő szerepe van például akut esetben vagy a tervezett ablatiós kezelési időpontig. Sikeres ablatiót követően a legtöbb esetben a gyógyszeres terápia elhagyható [12].

\section{A VT-ablatiók technikai háttere}

\section{Képalkotó eljárások}

A '90-es évek végén megjelent és folyamatosan fejlesztett elektroanatómiai térképezőrendszerek (EAM) sugárterhelés nélkül jelenítik meg a szívüreg térbeli anatómiáját, illetve annak elektromos aktivációját sinusrhythmus vagy egyéb ritmuszavar, akár VT során [13]. Ezek a rendszerek 3 fontos funkciót integrálnak: 1. az ablatiós katéter pontos térbeli helyzetének meghatározását; 2 . az adott anatómiai régió aktuális intracardialis elektrogram(EGM-) jellemzőinek tárolását (aktivációs idők, feszültség, morfológia); 3. az elektroanatómiai információk megjelenítését a szív 3D térképén. Magát a térbeli anatómiát pontról pontra történő multielektródás térképezéssel, intracardialis ultrahanggal (ICE), komputertomográfiával (CT) vagy mágneses rezonanciás (MR-) vizsgálattal lehet megjeleníteni. Többféle elektroanatómiai térképezőrendszer létezik, amelyek részletes bemutatása jelen cikkünk kereteit meghaladja, múködési elvüket korábbi írásunkban ismertettük [13]. Az EAMeket széleskörüen alkalmazzák strukturális szívbetegségekkel járó VT-k esetében [14]. Idiopathiás VT-k ablatiójánál az EAM-rendszerek hasznosak, de nem feltétlen szükségesek. 2009-ben az esetek mintegy 50\%-ában alkalmazták [7]. Az utóbbi években megjelentek a robot navigációs rendszerek, ahol a katéter mozgatása robotkar vagy mágneses mező segítségével történik. A mágneses navigációs rendszerek ( $\mathrm{RMN}$ ) előnye az alacsony sugárterhelés, valamint a gyorsabb és pontosabb ablatio. Ezek a rendszerek VT-k esetében is sikerrel alkalmazhatóak, holott valódi értékük VT-k ablatiójánál még nem egyértelmü [15].

A szív anatómiájának pontos ismerete, megértése és megjelenítése kiemelkedően fontos a térképezés során, illetve a tervezett ablatio elött. Legegyszerúbb módszer az echokardiográfiás (ECHO) vizsgálat, amely minden ritmuszavaros betegnél kötelezően elvégzendő a beavatkozás előtt, majd az ablatiót követően is. Segítségével a VT-szubsztrátként szolgáló szívbetegségek többsége jól vizualizálható, például falmozgászavar, heg, egyéb kóros szívizomstruktúra stb. A mágneses rezonanciás (MR-) készülékek fejlődésének köszönhetően egy jó felbontású MR-készülékkel sokkal részletesebb és pontosabb szubsztrátkeresés valósítható meg. A gond, hogy sok betegnél a már beültetésre került ICD-készülék miatt az intézetek nem végzik el a szív-MR-vizsgálatot, holott ennek biztonságossága - megfelelő programozással 1,5 T-ig - igazolt [16]. A komputertomográfiás (CT-) vizsgálatoknak inkább a koszorúér-betegségek nem invazív diagnosztikájában van kiemelkedő szerepe, de az utóbbi években az ECHO- és MR-képalkotók mellett egyre nagyobb szerepet kap a myocardium betegségeinek diagnosztikájában [17]. Az intracardialis echokardiográfia (ICE) is egyre gyakrabban kerül alkalmazásra az ablatio során. Segítségével jól vizualizálhatóak egyes szívüregi struktúrák vagy maga az ablatiós katéter. Előnye, hogy a beavatkozás alatti aktuális anatómiát jeleníti meg és a képalkotó eljárások további fejlesztésének is ez az egyik irányvonala.

\section{Energiaforrások}

Az RF-energiát használják a leggyakrabban az ablatiók során, egyszerúsége és jó hatékonysága miatt. Két fó technikai alkalmazása terjedt el: a klasszikus/standard RF-ablatio, valamint az irrigációs RF-ablatio. A két technikai alkalmazás részletes fizikai ismertetése a jelen cikk kereteit meghaladja, így a fontosabb információkat öszszegezzük.

Igazából nincs meghatározva egy standard optimális energialeadás például endocardialis ablatio során, hanem több energiatitrálási módszer terjedt el az EP-laborokban. A klasszikus 4-5 mm-es ablatiós katéterek használatakor általában 30-50 W-ot alkalmaznak hőmérséklet $\left(55-70{ }^{\circ} \mathrm{C}\right)$ vagy impedanciaesés $(10-15 \mathrm{ohm})$ folyamatos kontrollja mellett [18]. Az idiopathiás VT-k ablatiója során többnyire kis laesiók elégségesek, és sikerrel alkalmazzák a 4-5 mm-es standard RF-katétereket. Strukturális szívizombetegség (például hegszövet) esetén kiterjedt területen és mélyebben végeznek ablatiót, így nagyobb, 8-10 mm-es standard RF-katétereket vagy többnyire irrigációs RF-katétereket használnak [7]. Továbbra sincs randomizált vizsgálat a két módszer összehasonlítására VT-k ablatióját illetően, és mivel manapság a standard RF-katétereket már ezen a területen ritkán használják, erre a jövőben aligha lesz lehetőség. Az irrigációs katéterek a folyamatos hútés miatt nagyobb energiát igényelnek a megfelelő koagulációs hőmérséklet eléréséhez, ugyanakkor a laesio kiterjedtsége is nagyobb. Belső és külső irrigációs katéterek használatosak. A gyakorlatban inkább az utóbbiak terjedtek el, holott a volumenterhelés szívelégtelenség vagy például epicardialis ablatio során körültekintést igényel.

\section{A VT-ablatiók előkészítése}

A VT-k katéteres ablatiója egy komplex beavatkozás, és gyakran végzik előrehaladott szívbetegségben szenvedő betegeken, így a kezelés nem elhanyagolható rizikófaktorral rendelkezik. A tervezett beavatkozás előtt indokolt a teljes körû cardiovascularis kivizsgálás. A fizikális vizsgálaton, rutin-laborvizsgálaton és 12 csatornás EKG-n kívül további kiegészítő vizsgálatok (ECHO, er- 
gometria, 24-48 órás Holter-EKG, koronarográfia, CT, MR, LoopRecorder implantáció stb.) indokoltak a következő szempontok tisztázása céljából:

- szignifikáns koszorúér-betegség kizárása, amelynek revascularisatiója indokolt lenne;

- a szívizombetegség pontos etiológiájának és a szívizom érintettségének precíz meghatározása;

- a tartós/nem tartós VT-k dokumentálása, minőségi és mennyiségi pontos értékelése (morfológia, előfordulás gyakorisága, tartama, klinikum stb.).

\section{Strukturális szívizombetegséghez társuló VT-k ablatiója}

Ezt a csoportot ischaemiás és nem ischaemiás cardiomyopathiához (CMP) tartozó VT-re bonthatjuk. A leggyakoribb az ischaemiás VT, azon belül a korábbi szívizominfarktust követően fellépő ritmuszavar [19]. Ennek a mechanizmusa többnyire egy hegszövet/fibrosis talaján kialakuló „reentry” kör [20]. A nem ischaemiás CMPcsoportba soroljuk a minden egyéb okból kialakuló kamrai diszfunkciót, amely esetén a szívizomban legtöbbször fibrosis, ritkábban egyéb patológiás eltérés igazolható. Ennek lokalizációja, kiterjedése és mintázata a legszélsőségesebb keretek közt változhat a különböző CMP-k esetén. Idetartoznak a billentyúbetegségek talaján kialakuló CMP, a szívizomgyulladásokat követő CMP, sarcoidosis, hypertrophiás CMP, arhythmogen jobb kamrai cardiomyopathia (ARVC), Chagas-kór és a congenitalis szívbetegségek rekonstrukcióját követő VT-k [7].

Jelenleg a strukturális szívbetegséggel járó VT-k esetében javasolt a relatív korai katéterablatiós kezelés, a ritmuszavar progressziójának, illetve a többféle tartós gyógyszeres kezelés megelőzésének céljából. Ezt igazolja a multicentrikus Euro-VT-vizsgálat, ahol a betegek több mint 80\%-ában a klinikailag releváns VT-t a beavatkozást követően nem lehetett indukálni, és mindezt alacsony komplikációs ráta mellett érték el [14]. Egy másik multicentrikus randomizált vizsgálatban (VTACH) a posztinfarktusos, csökkent bal kamrai ejekciós frakcióval (LVEF $\leq 50 \%)$ rendelkező stabil VT-s betegeknél az ICD-implantáció előtt végzett RF-ablatio szignifikánsan megnyújtotta az első VT-recidíváig eltelt időt (18,6 hó vs. 5,9 hó) [21].

Az elmúlt években több elmélet és azt igazoló módszer került a mindennapi gyakorlatba, amelyek a strukturális szívbetegségekkel járó VT-k ablatiós kezelésében új perspektívákat eredményeztek. A klasszikus pace-térképezés és entrainment-térképezés mellett az EAM-mel végzett aktivációs térképezés, valamint legutóbb a szubsztráttérképezés alkalmazása terjedt el. Gyakran a felsorolt térképezési módszerek különböző kombinációit alkalmazzák, figyelemmel kísérve a jelentősebb lokális EGMeket [22]. A szubsztráttérképezés az utóbbi években egyre nagyobb figyelmet kapott, hiszen segítségével a nem tartós, az EP-vizsgálat alatt nem indukálható vagy a hemodinamikailag instabil VT-k is eredményesen ablál-
3. táblázat

Lokális elektrogramok (EGM) osztályozása

1. Normális EGM: bi- vagy trifázisos, magas amplitúdó $\geq 3 \mathrm{mV}$, szélesség $\leq 70 \mathrm{~ms}$.

2. Frakcionált EGM: alacsony amplitúdó $\leq 0,5 \mathrm{mV}$, tartósan fennáll ( $\geq 130 \mathrm{~ms})$ érdemi izoelektromos intervallum nélkül.

3. Késői potenciál: a lokális EGM-től különálló komponens, a felszíni QRS végétől minimum $\geq 10$ ms távolságra. Idetartozik az izolált diasztolés potenciál.

4. Izolált potenciál: a lokális EGM-tôl minimum $20-50 \mathrm{~ms}$ izoelektromos vonallal elválasztott potenciál.

5. Multipotenciális EGM: több mint egy különálló potenciált tartalmaz, köztük 30-50 ms izoelektromos vonal.

Leggyakoribb a split/kettős potenciált tartalmazó EGM.

hatók [23]. Ennek a módszernek a lényege, hogy a hegszövetet, illetve egyéb kóros régiót gyors EAM-térképezést követően azonosítjuk, majd a célrégióban az EGM-ek (1. ábra) morfológiai értékelését végezzük [24]. Az elemzést sinusrhythmusban vagy stimulálás alatt, egy adott osztályozás alapján (3. táblázat) végezzük, hogy a potenciális VT-gócokat azonosítsuk. Ezek jelentik az ablatiós célrégiókat is egyben.

Halmozott VES vagy indukálható tartós VT esetében többnyire EAM segítségével az aktivációs térkép készítése az első lépés. Fokális VT esetében a legkorábbi elektromos aktivitással jelentkező régió a VT gócpontját jelzi. Hegszövet/fibrosis asszociált reentry VT esetében az aktivációs térkép körültekintőbb értelmezést igényel. Amennyiben stabil a VT, a komplett aktivációs ciklust entrainment-térképezéssel ellenőrzik, az ablatiós célrégiók precíz megjelölése céljából. A pace-térképezést mindkét mechanizmus esetében segítségként alkalmazzák, természetesen ismerve ennek korlátait [25].

\section{Idiopathiás VT-k ablatiója}

Ezek a ritmuszavarok többnyire fiatalabb életkorban jelentkeznek (3-5. évtized), és alacsony mortalitással jellemezhetők [26]. Fontos kiemelni, hogy habár az idiopathiás fokális VT-k többnyire strukturális szívbetegség hiányában jelentkeznek, MR-vizsgálatok során gyakran rendellenes falmozgást írtak le, amelyek felvetik a strukturális rendellenesség gyanúját $[27,28]$. Az idiopathiás VT-k mechanizmusa fokális automácián vagy többnyire triggerelt aktivitáson alapul. Ez utóbbi magas intracelluláris $\mathrm{Ca}^{2}$-koncentrációhoz és ezáltal elhúzódó utódepolarizációhoz vezet [29]. Ez megmagyarázza a ritmuszavar indulását fizikai aktivitás során vagy isoproterenol adását követően.

\section{Kiáramlási pálya VT-ik}

Az idiopathiás VT-k mintegy 70-80\%-a jobb vagy bal kiáramlási pályából (RVOT/LVOT) ered. 12 elvezetéses EKG-n szárblokkos morfológia és meredek tengelyállás 


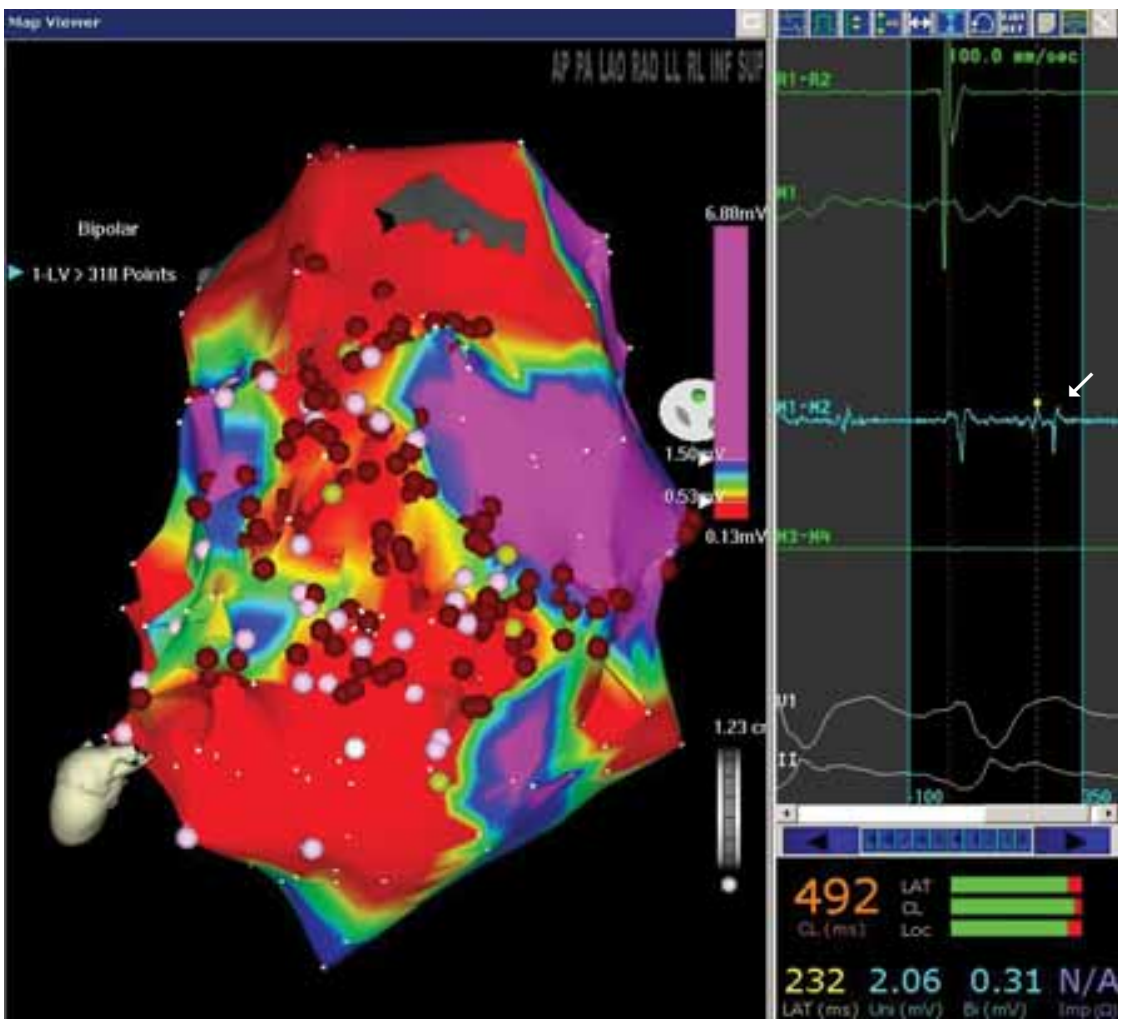

1. ábra

\begin{tabular}{|l}
$\begin{array}{l}\text { Posztinfarktusos VT ablatiója. Az elektroanatómiai térképen (nagyobb kép) piros színnel jelölt hegszövet területéról alacsony amplitúdójú EGM-ek } \\
\text { (kis kép, kék szín) regisztrálhatók. Itt látható az izolált késői potenciál (nyillal jelölve) }\end{array}$ \\
EGM = elektrogram; VT = kamrai tachycardia
\end{tabular}

jellemző. Az RVOT-VT esetében az R/S átmeneti zóna többnyire a $\mathrm{V}_{3}$-as elvezetés után következik (2. ábra), míg az LVOT-VT esetében az $\mathrm{R} / \mathrm{S}$ átmenet $\mathrm{V}_{3}$-ban vagy az előtt jelentkezik [30]. Egyes esetekben az RVOT-VT vagy az ebből a régióból induló halmozott VES-tevékenység az ARVC egyes megjelenési formáival diagnosztikai problémát jelenthet. Igaz, utóbbi esetben az epszilon-hullám a $\mathrm{V}_{1-2}$-elvezetésekben, illetve negatív T-hullám a $\mathrm{V}_{1-3}$-elvezetésekben irányadó lehet [31].

Ezekben az esetekben a pontról pontra történő elektroanatómiai térképezés az általában használatos technika. Az ablatiós katéter bipoláris $(>1,5 \mathrm{mV}$ ) és unipoláris (éles QRS mély, negatív deflexióval) nem fragmentált jelei az irányadóak, amelyek a felszíni QRS-t 10-60 msmal előzik meg [32]. Gyakran pace-térképezést is végeznek kiegészítésként, különösen azokban az esetekben, ha a célrégió spontán aktivitása a beavatkozás alatt nem jelentkezik. A pace-térképezés térbeli felbontásának korlátait ismerni kell, hiszen egyes betegeknél egy maximálisan egyező pace-térkép lokalizálható akár $2 \mathrm{~cm}$-es távolságra a VT igazi gócpontjától [33].

\section{Intrafascicularis VT-k}

Az idiopathiás VT-k mintegy 6\%-a kerül ebbe a csoportba, és alapja egy reentry mechanizmus, amelynek része a bal posterior, ritkábban a bal anterior fasciculus. Ennek megfelelően történik a csoportosításuk, illetve az emlí- tett 2 alcsoport mellett még leírtak egy nagyon ritka, úgynevezett felső septalis fascicularis VT-t, keskeny QRS-sel [34]. Amennyiben perzisztens formában jelentkezik, az a szív megnagyobbodásához vezethet, amely verapamilterápiára teljes regressziót mutat [35]. A 12 elvezetéses EKG-n jobbszár-blokkos morfológia látható bal anterior vagy bal posterior hemiblokkal. Az ablatio során a ciklus kilépési pontja környékén éles, preszisztolés potenciálokat (fúziós Purkinje-potenciálok) vagy a fasciculus leszálló ágán diasztolés potenciálokat keresnek [36]. Az RF-ablatio sikeraránya 95\% fölött van [36].

\section{Fokális Purkinje-VT-k}

Ezt a csoportot a Purkinje-rendszerben fellépő kóros automácia jellemzi [37] és az idiopathiás VT-k kevesebb mint 5\%-át teszik ki. Malignus formája az idiopathiás kamrafibrilláció (VF), amelyet ugyancsak a Purkinjerendszerben fellépő fokális aktivitás vált ki [38]. Fontos, hogy a fokális Purkinje-VT nem verapamilérzékeny és 12 elvezetéses EKG-n az előbbi verapamilérzékeny csoporttól alig különböztethető meg [39]. Programozott kamrai ingerléssel nem befolyásolható, ellenben terheléssel vagy katecholaminokkal indukálható, és érzékeny lidokain vagy béta-blokkoló terápiára. Itt az ablatio során, a fennálló VT alatt, a legkorábbi Purkinje-potenciál megkeresése a cél. Sinusrhythmus esetén ezen a helyen fúziós Purkinje-potenciálok láthatók [39]. 
a)

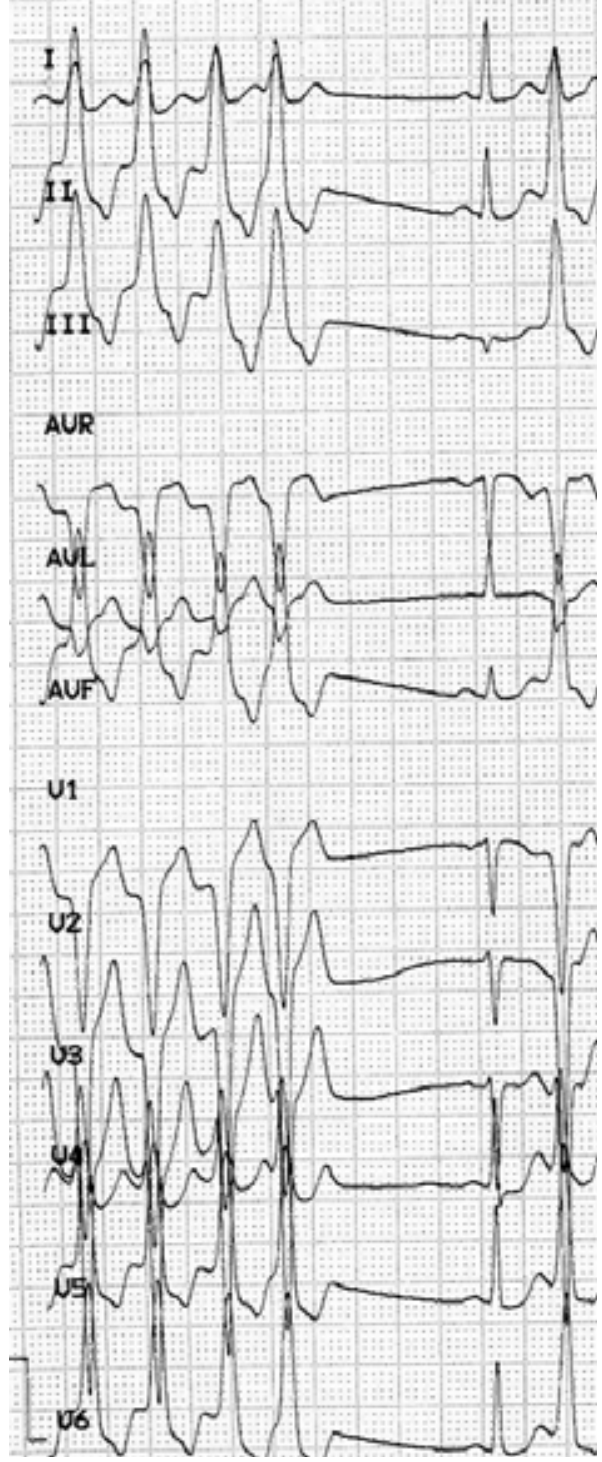

b)

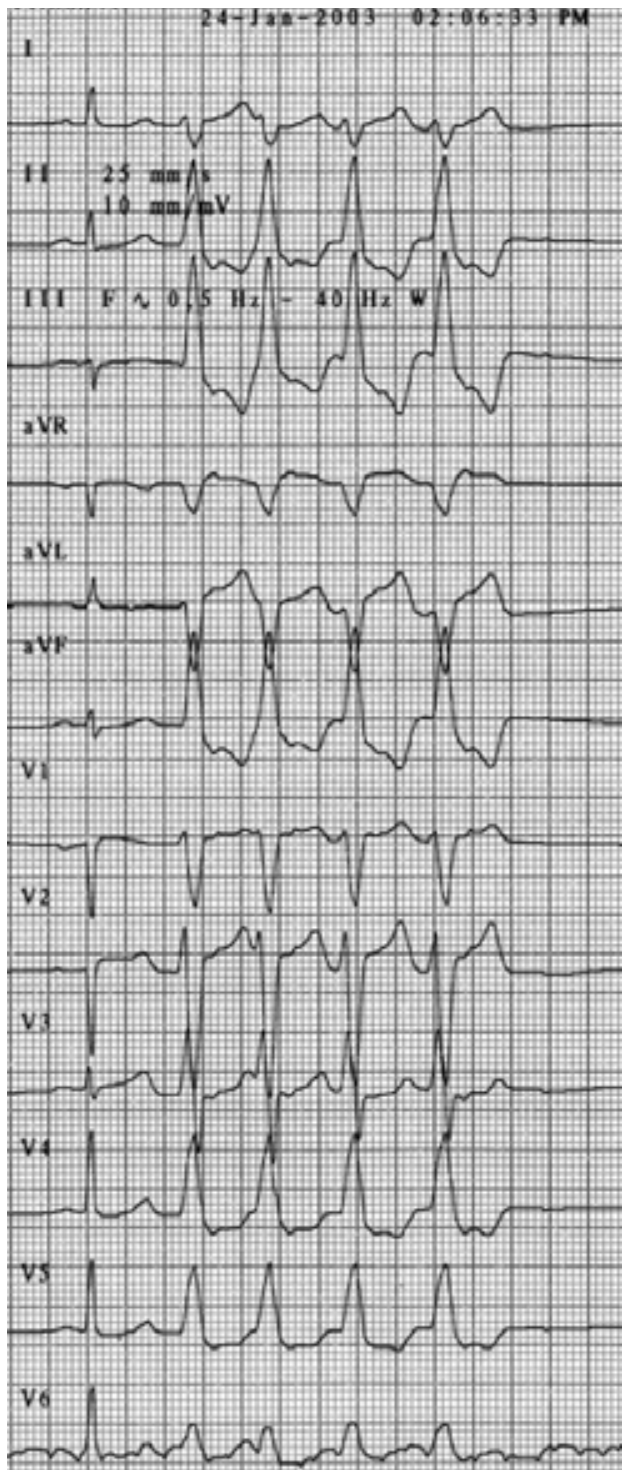

2. ábra

RVOT (a) és LVOT (b) standard 12 elvezetéses EKG-ja. Jellemző, hogy RVOT esetén az R/S átmeneti zóna többnyire a $\mathrm{V}_{3}$-as elvezetés után következik, míg LVOT-nál előbb

LVOT = bal kamrai kiáramlási pálya tachycardia; RVOT = jobb kamrai kiáramlási pálya tachycardia

\section{Epicardialis ablatio}

A VT-góc epicardiumhoz közeli elhelyezkedése eredményezheti az endocardialis ablatio sikertelenségét. Ez esetben a sikeres beavatkozáshoz epicardialis ablatio szükséges. Többnyire nem ischaemiás cardiomyopathiák talaján kialakult VT-k kerülnek ebbe a csoportba [40]. Az epicardialis ablatio indikációja az esetek többségében a térképezés során merül fel (aktivációs, entrainment-, pace- és/vagy szubsztráttérképezés), de jellegzetes EKGeltérések is felvethetik ennek szükségességét [41]. Az epicardialis ablatio során az RF-energia leadásakor különös figyelemmel kell lenni a nervus phrenicus vagy a koszorúerek anatómiájára. Az ablatiót követően az esetek mintegy 30\%-ában pericarditis tünetei jelentkeznek, amelyek gyulladásos terápiára napok alatt rendeződnek [42].

\section{Polimorf VT-k és VF ablatioja}

A polimorf VT-k és VF többnyire elektromos vihar formájában jelentkeznek. Ilyenkor béta-blokkoló, amiodaron-, prokainamid- vagy lidokainterápia egyaránt hatásos lehet, ugyanúgy, mint az általános anesztézia [8]. Mindezek mellett a katéteres ablatiónak kiemelkedő szerepe van, különösen posztinfarktusos állapot, Brugada- vagy long QT-szindróma, kiáramlási ectopia vagy idiopathiás VF esetén [8]. A VT-k ezen csoportjánál a ritmuszavar alapja a cikkben felsorolt bármelyik mechanizmus lehet, így az ablatiós stratégia is széles skálán mozog. A sikerarány, különösen ismert vagy valószínúsített trigger felismerése esetén, 24-33 hónapos utánkövetési idő alatt 89-100\% közt mozog [38, 43]. 


\section{Következtetések}

Az utóbbi két évtizedben a katéterablatiós technológia és az ablatiós stratégiák fejlődésével jelentős előrelépés történt a VT-k ablatiós kezelésében. Ez a módszer megfelelő indikáció, illetve tárgyi és szakmai feltétel mellett biztonságos és sikeres eszközös terápiás beavatkozást jelent. Az új elektroanatómiai térképezési és ablatiós ismereteknek köszönhetően manapság a nem indukálható vagy hemodinamikailag instabil VT-k is magas sikeraránnyal kezelhetők. Összegzésképpen kijelenthető, hogy a katéteres ablatiót többnyire korán be kell iktatni a terápiába, mielőtt az ismételten fellépő VT-k miatt egyéb károsodás vagy egyre gyakoribb ICD-terápiás beavatkozás fellépne.

Anyagi támogatás: A közleményhez kapcsolódó kutatómunka és a közlemény megírása anyagi támogatásban nem részesült.

Szerzői munkamegosztás: M. A.: Kutatómunka. T. K., Sz.-T. T.: A kézirat szerkesztése. M. A., T. K., Sz.-T. T.: A kézirat szövegezése. A cikk végleges változatát valamennyi szerző elolvasta és jóváhagyta.

Érdekeltségek: A szerzőknek nincsenek érdekeltségeik.

\section{Irodalom}

[1] Prystowsky, E. N., Padanilam, B. J., Joshi, S., et al.: Ventricular arrhythmias in the absence of structural heart disease. J. Am. Coll. Cardiol., 2012, 59(20), 1733-1744.

[2] Jacobson, J. T., Weiner, J. B.: Management of ventricular tachycardia in patients with structural heart disease. Cardiovasc. Ther., $2010,28(5), 255-263$.

[3] Harken, A. H., Horowitz, L. N., Josephson, M. E.: The surgical treatment of ventricular tachycardia. Ann. Thorac. Surg., 1980, 30(5), 499-508.

[4] Hartzler, G. O.: Electrode catheter ablation of refractory focal ventricular tachycardia. J. Am. Coll. Cardiol., 1983, 2(6), $1107-$ 1113.

[5] Santangeli, P., Infusino, F., Sgueglia, G. A., et al.: Ventricular late potentials: a critical overview and current applications. J. Electrocardiol., 2008, 41(4), 318-324.

[6] Avitall, B., Khan, M., Krum, D. J., et al.: Physics and engineering of transcatheter cardiac tissue ablation. J. Am. Coll. Cardiol., 1993, 22(3), 921-932.

[7] Aliot, E. M., Stevenson, W. G., Almendral-Garrote, J. M., et al. EHRA/HRS Expert Consensus on Catheter Ablation of Ventricular Arrhythmias: developed in a partnership with the European Heart Rhythm Association (EHRA), a Registered Branch of the European Society of Cardiology (ESC), and the Heart Rhythm Society (HRS); in collaboration with the American College of Cardiology (ACC) and the American Heart Association (AHA). Europace, 2009, 11(6), 771-817.

[8] Pedersen, C. T., Kay, G. N., Kalman, J., et al.: EHRA/HRS/ APHRS expert consensus on ventricular arrhythmias. Europace, 2014, 16(9), 1257-1283.

[9] Prystowsky, E. N.: Primary and secondary prevention of sudden cardiac death: the role of the implantable cardioverter defibrillator. Rev. Cardiovasc. Med., 2001, 2(4), 197-205.
[10] Moss, A. J., Greenberg, H., Case, R. B., et al.: Long-term clinical course of patients after termination of ventricular tachyarrhythmia by an implanted defibrillator. Circulation, 2004, 110(25), 3760-3765.

[11] Bollmann, A., Husser, D., Cannom, D. S.: Antiarrhythmic drugs in patients with implantable cardioverter-defibrillators. Am. J. Cardiovasc. Drugs, 2005, 5(6), 371-378.

[12] Stewenson, W. G.: Current treatment of ventricular arrhythmias: state of the art. Heart Rhythm, 2013, 10(12), 1919-1926.

[13] Mibálcz, A., Tahin, T., Szili-Török, T.: Electroanatomical mapping systems in catheter ablation of cardiac arrhythmias. [Elektroanatómiai térképező rendszerek a ritmuszavarok katéterablatiós kezelésében.] Orv. Hetil., 2008, 149(25), 1155-1160. [Hungarian]

[14] Tanner, H., Hindricks, G., Volkmer, M., et al.: Catheter ablation of recurrent scar-related ventricular tachycardia using electroanatomical mapping and irrigated ablation technology: results of the prospective multicenter Euro-VT-Study. J. Cardiovasc. Electrophysiol., 2010, 21(1), 47-53.

[15] Akca, F., Önsesveren, I., Jordaens, L., et al.: Safety and efficacy of the remote magnetic navigation for ablation of ventricular tachycardias - a systematic review. J. Interv. Card. Electrophysiol., 2012, 34(1), 65-71.

[16] Roguin, A., Schwitter, J., Vablhaus, C., et al.: Magnetic resonance imaging in inviduals with cardiovascular implantable electronic devices. Europace, 2008, 10(3), 336-346.

[17] Clayton, B., Roobottom, C., Morgan-Hughes, G.: Assessment of the myocardium with cardiac computed tomography. Eur. Heart J. Cardiovasc. Imaging, 2014, 15(6), 603-609.

[18] Matsudaira, K., Nakagawa, H., Wittkampf, F. H., et al.: High incidence of thrombus formation without impedance rise during radiofrequency ablation using electrode temperature control. Pacing Clin. Electrophysiol., 2003, 26(5), 1227-1237.

[19] Jacobson, J. T., Weiner, J. B.: Management of ventricular tachycardia in patients with structural heart disease. Cardiovasc. Ther., $2010,28(5), 255-263$.

[20] Stevenson, W. G.: Ventricular scars and ventricular tachycardia. Trans. Am. Clin. Climatol. Assoc., 2009, 120, 403-412.

[21] Kuck, K. H., Schaumann, A., Eckardt, L., et al.: Catheter ablation of stable ventricular tachycardia before defibrillator implantation in patients with coronary heart disease (VTACH): a multicentre randomised controlled trial. Lancet, 2010, 375(9708), $31-40$.

[22] Haqquani, H. M., Marchlinski, F. E.: Electrophysiologic substrate underlying postinfarction ventricular tachycardia: characterization and role in catheter ablation. Heart Rhythm, 2009, 6(8 Suppl.), S70-S76.

[23] Campos, B., Jauregui, M. E., Marchlinski, F. E., et al.: Use of a novel fragmentation map to identify the substrate for ventricular tachycardia in postinfarction cardiomyopathy. Heart Rhythm, 2015, 12(1), 95-103.

[24] Josephson, M. E.: Clinical cardiac electrophysiology: Techniques and interpretations. 4th ed. Lippincott Williams and Wilkins, Philadelphia, 2008.

[25] Meyer, C., Martinek, M., Pürerfellner, H.: Katheterablation ventrikulärer Tachykardien. Austr. J. Cardiol., 2011, 18(3-4), 8795.

[26] Shimizu, W.: Arrhythmias originating from the right ventricular outflow tract: how to distinguish "malignant" from "benign"? Heart Rhythm, 2009, 6(10), 1507-1511.

[27] Sinha, S., Calkins, H.: Idiopathic right ventricular outflow tract tachycardia: no longer idiopathic? J. Cardiovasc. Electrophysiol., 2006, 17(7), 776.

[28] Tandri, H., Bluemke, D. A., Ferrari, V. A., et al.: Findings on magnetic resonance imaging of idiopathic right ventricular outflow tachycardia. Am. J. Cardiol., 2004, 94(11), 1441-1445.

[29] Yamawake, N., Nishizaki, M., Hayashi, T., et al.: Autonomic and pharmacological responses of idiopathic ventricular tachycardia 
arising from the left ventricular outflow tract. J. Cardiovasc. Electrophysiol., 2007, 18(11), 1161-1166.

[30] Yamada, T., Yoshida, N., Murakami, Y., et al.: Electrocardiographic characteristics of ventricular arrhythmias originating from the junction of the left and right coronary sinuses of Valsalva in the aorta: the activation pattern as a rationale for the electrocardiographic characteristics. Heart Rhythm, 2008, 5(2), 184-192.

[31] Marcus, F. I., McKenna, W. J., Sherrill, D., et al.: Diagnosis of arrhythmogenic right ventricular cardiomyopathy/dysplasia: proposed modification of the task force criteria. Circulation, 2010, 121(13), 1533-1541.

[32] Hutchinson, M. D., Garcia, F. C.: An organized approach to the localization, mapping, and ablation of outflow tract ventricular arrhythmias. J. Cardiovasc. Electrophysiol., 2013, 24(10), 1189-1197.

[33] Bogun, F., Taj, M., Ting, M., et al.: Spatial resolution of pace mapping of idiopathic ventricular tachycardia/ectopy originating in the right ventricular outflow tract. Heart Rhythm, 2008, 5(3), 339-344.

[34] Shimoike, E., Ueda, N., Marnyama, T., et al.: Radiofrequency catheter ablation of upper septal idiopathic left ventricular tachycardia exhibiting left bundle branch block morphology. J. Cardiovasc. Electrophysiol., 2000, 11(2), 203-207.

[35] Littmann, L., Kempler, P., Robla, M., et al.: Ventricular tachycardia treated with verapamil. [Verapamillal kezelt kamrai tachycardia.] Orv. Hetil., 1988, 129(5), 247-250. [Hungarian]

[36] Arya, A., Haghjoo, M., Emkanjoo, Z., et al.: Comparison of presystolic Purkinje and late diastolic potentials for selection of ablation site in idiopathic verapamil sensitive left ventricular tachycardia. J. Interv. Card. Electrophysiol., 2004, 11(2), 135-141.
[37] Metzner, A., Ouyang, F., Wissner, E., et al.: Monomorphic and polymorphic ventricular tachycardias arising from the HisPurkinje system: what do we know? Future Cardiol., 2011, 7(6), 835-846.

[38] Haïsaguerre, M., Shah, D. C., Jaïs, P., et al.: Role of Purkinje conducting system in triggering of idiopathic ventricular fibrillation. Lancet, 2002, 359(9307), 677-678.

[39] Gonzalez, R. P., Scheinman, M. M., Lesh, M. D., et al.: Clinical and electrophysiologic spectrum of fascicular tachycardias. Am. Heart J., 1994, 128(1), 147-156.

[40] Tedrow, U., Stevenson, W. G.: Strategies for epicardial mapping and ablation of ventricular tachycardia. J. Cardiovasc. Electrophysiol., 2009, 20(6), 710-713.

[41] Piers, S. R., de Riva Silva, M., M., Kapel, G. F., et al.: Endocardial or epicardial ventricular tachycardia in nonischemic cardiomyopathy? The role of 12-lead ECG criteria in clinical practice. Heart Rhythm, 2014, 11(6), 1031-1039.

[42] Yamada, T.: Transthoracic epicardial catheter ablation: indications, techniques, and complications. Circ. J., 2013, 77(7), 1672-1680.

[43] Bänsch, D., Oyang, F., Antz, M., et al.: Successful catheter ablation of electrical storm after myocardial infarction. Circulation, 2003, 108(24), 3011-3016.

(Mihálcz Attila dr., Budapest, Haller u. 29., 1096 e-mail: amihalcz@hotmail.com)

\section{A rendezvények és kongresszusok híranyagának leadása}

a lap megjelenése előtt legalább 40 nappal lehetséges, a 6 hetes nyomdai átfutás miatt. Kérjük megrendelőink szíves megértését.

A híranyagokat a következő címre kérjük: Orvosi Hetilap titkársága: Budai.Edit@akkrt.hu Akadémiai Kiadó Zrt. 